Advances in Invertebrates and Fish Telemetry 
Developments in Hydrobiology 130

Series editor

H. J. Dumont 


\title{
Advances in Invertebrates and Fish Telemetry
}

Proceedings of the Second Conference on Fish Telemetry in Europe, held in La Rochelle, France, 5-9 April 1997

\author{
Edited by \\ Jean-Paul Lagardère, Marie-Laure Bégout Anras \& Guy Claireaux
}

Reprinted from Hydrobiologia, volumes $371 / 372$ (1998) 
A C.I.P. Catalogue record for this book is available from the Library of Congress.

ISBN 978-94-010-6138-4

ISBN 978-94-011-5090-3 (eBook)

DOI 10.1007/978-94-011-5090-3

Printed on acid-free paper

All rights reserved

(C)1998 Springer Science+Business Media Dordrecht

Originally published by Kluwer Academic Publishers in 1998

Softcover reprint of the hardcover 1st edition

No part of the material protected by this copyright notice may be reproduced

or utilized in any form or by any means, electronic or mechanical,

including photocopying, recording or by any information storage and

retrieval system, without written permission from the copyright owner. 


\section{Contents}

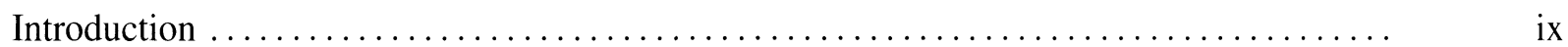

Scientific Committee/Editorial Board/List of Sponsors $\ldots \ldots \ldots \ldots \ldots \ldots \ldots \ldots \ldots \ldots \ldots \quad \mathrm{x}$

List of Participants $\ldots \ldots \ldots \ldots \ldots \ldots \ldots \ldots \ldots \ldots \ldots \ldots \ldots \ldots \ldots \ldots \ldots \ldots \ldots \ldots \ldots \ldots \ldots \ldots \ldots \ldots \ldots \ldots$

\section{Methodology and New Developments}

Applications and performance of Radio-Acoustic Positioning and Telemetry (RAPT) systems by R.K. O’Dor, Y. Andrade, D.M. Webber, W.H.H. Sauer, M.J. Roberts, M.J. Smale \&

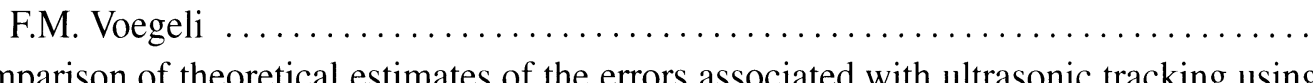

A comparison of theoretical estimates of the errors associated with ultrasonic tracking using a fixed hydrophone array and field measurements

by G.W. Smith, G.G. Urquhart, D.N. MacLennan \& B. Sarno . . . . . . . . . . . .

Selection of optimal positioning intervals in fish tracking: an experimental study on Barbus barbus

by E. Baras

Inland migration study of sea trout (Salmo trutta) into the rivers Rhine and Meuse (The Netherlands), based on inductive coupling radio telemetry

by A.W. Breukelaar, A. bij de Vaate $\&$ K.T.W. Fockens $\ldots \ldots \ldots \ldots \ldots \ldots \ldots \ldots$

Development of miniature pingers for tracking Atlantic salmon smolts at sea

by F.A. Voegeli, G.L. Lacroix \& J.M. Anderson .

A dynamic combined acoustic and radio-transmitting tag for diadromous fish

by G.H. Niezgoda, R.S. McKinley, D. White, G. Anderson \& D. Cote . . . . . . . . . Frequency choice for radio telemetry: the HF vs. VHF conundrum

by M.M. Sisak \& J.S. Lotimer . . . . . . . . . . . . . . . . . . . . .

Simultaneous observations of tuna movements and their prey by sonic tracking and acoustic surveys

by E. Josse, P. Bach \& L. Dagorn

A data logger tag for the study of slaughter procedures in aquacultured salmon

by O.A. Olsen, P.O. Skjervold \& O. Fjaera

\section{Tagging Procedures}

Growth and physiological responses to surgical and gastric radio transmitter implantation techniques in subyearling chinook salmon (Oncorhynchus tshawytscha)

by T.L. Martinelli. H.C. Hansel \& R.S. Shively ......................

Use of miniature radio-tran smitters to track the movements of dace, Leuciscus leuciscus (L.) in the River Frome, Dorset

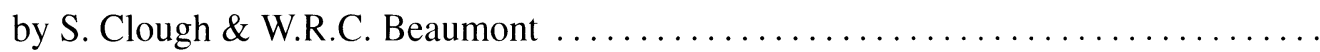


The effects of Passive Integrated Transponder tags on survival and growth of juvenile brown trout (Salmo trutta L.) and their use for studying movements in a small river

by D. Ombredane, J.L. Baglinière \& F. Marchand

Evaluation of surgery procedures for tagging eel Anguilla anguilla (L.) with biotelemetry transmitters

by E. Baras \& D. Jeandrain

$10 \%-111$

A method for the external attachment of acoustic tags on roundfish

by G. Claireaux \& C. Lefrançois . . . . . . . . . . . . . . . . . . . . .

Regurgitation rates of intragastric transmitters by adult Atlantic salmon (Salmo salar L.) during riverine migration

by G.W. Smith, R.N.B. Campbell \& J.S. MacLaine

\section{Behavioural and Physiological Ecology}

New approaches to the behavioural ecology of decapod crustaceans using telemetry and electronic tags

by J. Freire \& E. González-Gurriarán $\ldots \ldots \ldots \ldots \ldots \ldots \ldots \ldots \ldots \ldots \ldots \ldots \ldots \ldots \ldots \ldots \ldots \ldots$

Electromagnetic telemetry of lobster (Homarus gammarus (L.)) movements and activity: preliminary results

by I.P. Smith, K.J. Collins \& A.C. Jensen ......................

Basic movement pattern and chemo-oriented search towards baited pots in edible crab (Cancer pagurus L.)

by K. Skajaa, A. Fernö, S. Løkkeborg \& E.K. Haugland ................ Telemetry applied to behaviour analysis of yellowfin tuna (Thunnus albacares, Bonnaterre, 1788) movements in a network of fish-aggregating devices

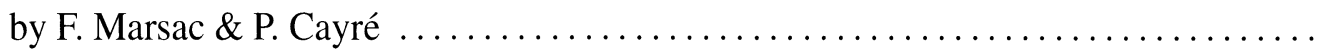

Spawning migration of radio-tagged landlocked Arctic Charr, Salvelinus alpinus L. in Ennerdale Lake, the English Lake District

by D.J.F. McCubbing, B.D. Bayliss \& V.M. Locke

Acoustic tracking of the dispersal of organic matter by scavenging fishes in the deep-sea

by M.A. Collins, I.G. Priede, S. Addison, A. Smith \& P.M. Bagley . . . . . . . . . . .

Seasonal variations in time and space utilization by radio-tagged yellow eels Anguilla anguilla (L.) in a small stream

by E. Baras, D. Jeandrain, B. Serouge \& J.C. Philippart

Reactions of cod (Gadus morhua L.) in the pre-vessel zone to an approaching trawler under different light conditions: preliminary results

by A. Engås, E.K. Haugland \& J.T. Øvredal

199--206

Changes in vertical distribution of sea bass (Dicentrarchus labrax L.) during a hypoxic episode

by H. Schurmann, G. Claireaux \& H. Chartois ....................

Heart rate telemetry to study environmental influences on fish metabolic cxpenditure

by C. Lefrançois, G. Claireaux \& J-P. Lagardère .....................

Effects of thermal environment on electromyographical signals obtained from Atlantic salmon (Salmo salar L.) during forced swimming

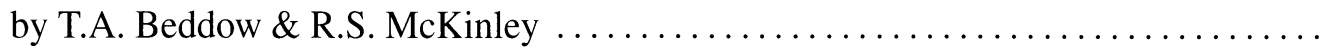


Remote monitoring of heart rate as a measure of recovery in angled Atlantic salmon, Salmo salar (L.)

by W.G. Anderson, R. Booth, T.A. Beddow, R.S. McKinley, B. Finstad, F. Økland \&

D. Scruton

Using speed-sensing transmitters to construct a bioenergetics model for subadult lemon sharks, Negaprion brevirostris (Poey), in the field

by L.F. Sundström \& S.H. Gruber

\section{Fish Migration and Stock Management}

Migratory and reproductive activity of radio-tagged Arctic char (Salvelinus alpinus L.) in northern Labrador

by T.A. Beddow, C. Deary \& R.S. McKinley $\ldots \ldots \ldots \ldots \ldots \ldots \ldots \ldots \ldots \ldots \ldots \ldots \ldots \ldots \ldots \ldots \ldots \ldots$

Environmental unpredictability rules the autumn migration of brown trout (Salmo trutta L.) in the Belgian Ardennes

by M. Ovidio, E. Baras, D. Goffaux, C. Birtles \& J.C. Philippart Spawning migration of sea trout (Salmo trutta (L.)) in a Danish river

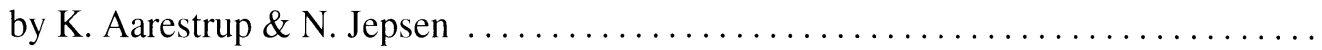

A radio telemetry study of the migration of Atlantic salmon (Salmo salar L.) and sea trout (Salmo trutta trutta L.) in the upper Rhine

by M. Gerlier \& P. Roche

The migratory behaviour of wild Atlantic salmon (Salmo salar L.) smolts in the River Test and Southampton Water, southern England

by A. Moore, S. Ives, T.A. Mead \& L. Talks $\ldots \ldots \ldots \ldots \ldots \ldots \ldots \ldots \ldots \ldots \ldots \ldots \ldots \ldots \ldots \ldots \ldots$

Movements of a bream (Abramis brama (L.)), rudd $\times$ bream hybrid, tench (Tinca tinca (L.)) and pike (Esox lucius (L.)) in an Irish canal habitat

by R.E. Donnelly, J.M. Caffrey \& D.M. Tierney ...................

Radio telemetry as a tool to study habitat use of nase (Chondrostoma nasus L.) in mediumsized rivers

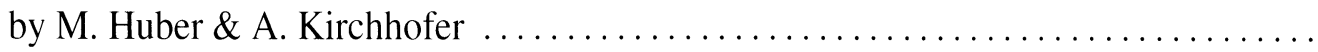

The migratory behaviour of juvenile and adult salmonids in relation to an estuarine barrage

by I.C. Russell, A. Moore, S. Ives, L.T. Kell, M.J. Ives \& R.O. Stonehewer . . . . . . . .

Movements of adult sea trout Salmo trutta L. in the tailrace of a low-head dam at Włocławek hydroelectric station on the Vistula River, Poland

by V.D. Linnik, L.K. Malinin, M. Wozniewski, R. Sych \& P. Dembowski

Migration of adult Atlantic salmon (Salmo salar (L.)); the effects of artificial freshets

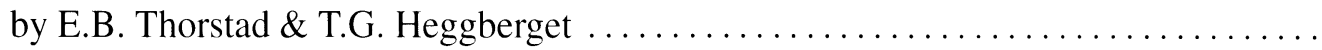

Survival of radio-tagged Atlantic salmon (Salmo salar (L.)) and trout (Salmo trutta L.) smolts passing a reservoir during seaward migration

by N. Jepsen, K. Aarestrup, G. Rasmussen \& F. Økland ....................

The efficiency of a nature-like bypass channel for pike-perch (Stizostedion Iucioperca (L.)) in the Marchfeldkanalsystem

by S. Schmutz, C. Giefing \& C. Wiesner 


\section{Introduction}

The Second Conference on Fish Telemetry in Europe was held in La Rochelle, France, from 5 to 9 April 1997. The aim of this conference was to facilitate exchanges between groups of researchers working on different compartments of marine or freshwater ecosystems and sharing telemetry techniques as investigating tools. This kind of conference also allows us to be informed of the most recent technical advances and associated conceptual developments.

After the success of the First Conference on Fish Telemetry held in Liège, Belgium, April 4-6, 1995, the presence of 110 participants from 17 countries attending this second conference confirmed that telemetry is establishing itself as a major technique for the analysis and management of aquatic ecosystems. With 57 oral and posted contributions presented, we can observe:

- a fast instrumental progression based on electronic and signal treatment advances,

- an enlargement of continuous investigation on aquatic animals tracked over wider areas (lakes, estuaries and coastal areas) and longer periods of time,

- a developing use of telemetry for aquatic animal stock management and the conservation and protection of their environment.

Forty manuscripts were selected by the organizing committee after being reviewed by members of the Editorial Board. They provide the material for this book and are organized into four sections:

1. Methodology and New Developments,

2. Tagging Procedures,

3. Behavioural and Physiological Ecology,

4. Fish Migration and Stock Management.

The organization of the Second Conference on Fish Telemetry in Europe was made possible by the support of Maurice Héral, Director, and the staff of the Centre de Recherche en Ecologie Marine et Aquaculture de I'Houmeau (CREMA). Special thanks are due to Miss A. Bonpain, Mrs A. L. Monteragioni and Mrs E. Travers, who undertook the secretarial work. We also thank Henri J. Dumont, Editor-in-Chief of Hydrobiologia and René Mijs, Kluwer Academic Publishers, for their interest in the production of this special issue.

CREMA (CNRS - Ifremer)

B.P. 5, 17137 L'Houmeau, France
J.-P. LAGARDÈRE

M.-L. BÉGOUT ANRAS

G. ClaireauX 


\section{Scientific Committee}

J. L. BAGLINIÈRE, INRA Rennes, France

E. BARAS, University of Liège, Belgium

G. CLAIREAUX, CREMA L'Houmeau, France

K. COLLINS, University of Southampton, U.K.

J. FREIRE, University of Coruna, Spain

T. HEGGBERGET, NINA Trondheim, Norway

J.-P. LAGARDÈRE, CREMA L'Houmeau,

France

A. MOORE, MAFF Lowestoft, U.K

I. G. PRIEDE, University of Aberdeen, U.K.

G. URQUHART, SOAFD Aberdeen, U.K.

H. WESTERBERG, National Board of Fisheries,

Sweden

\section{Editorial Board}

J. ARMSTRONG, Freshwater Fisheries Latıratory, U.K.

J. L. BAGLINIERE, INRA Rennes, France

E. BARAS, University of Liège, Belgium

M.-L. BÉGOUT ANRAS, CREMA L'Houme:ı, France

G. CLAIREAUX, CREMA L'Houmeau, France

K. J. COLLINS, University of Southampton, U.K.

J. FREIRE, University of Coruna, Spain

T. G. HEGGBERGET, NINA Trondheim, Norway

J. P. LAGARDÈRE, CREMA L'Houmeau, Frc nce

S. LOKKEBORG, Institute of Marine Research, Norway

A. MOORE, MAFF Lowestoft, U.K.

I. G. PRIEDE, University of Aberdeen, U.K.

G. W. SMITH, Freshwater Fisheries Laborato y, U.K.

I. P. SMITH, Southampton Oceanography, U.K.

G. G. URQUHART, SOAFD Aberdeen, U.K.

D. M. WEBBER, Dalhousie University, Canada

H. WESTERBERG, National Board of Fisheries, Sweden

\section{List of sponsors}

\section{Tutorial organisms}

Centre National de la Recherche Scientifique, CNRS

Institut Français de Recherche pour l'Exploitation de la Mer, IFREMER

Région Poitou Charentes, Programme Com'Sciences

Other sponsors

- Institut National de la Recherche Agronomique, INRA

- Institut Français de Recherche Scientifique pour le Développement en Coopération, ORSTOM

- Conseil Supérieur de la Pêche, CSP

- Conseil Général de la Charente Maritime

- Ville de La Rochelle

- Muséum d'Histoires Naturelles de La Rochelle

- Aquarium de La Rochelle

- Fish Eagle

- Lotek

- Vemco Ltd. 


\section{List of Participants}

\begin{tabular}{|c|c|c|c|}
\hline Kim AARESTRUP & Denmark & François LAUTERS & France \\
\hline Gary ANDERSON & Canada & Cheryl LE DREW & Canada \\
\hline Marie-Laure BÉGOUT ANRAS & France & Christel LEFRANÇOIS & France \\
\hline John ARMSTRONG & U.K. & Mario LEPAGE & France \\
\hline Bjorn Erik AXELSEN & Norway & Jeffrey LINES & U.K. \\
\hline Jean-Luc BAGLINIÈRE & France & Vladimir LINNIK & Russia \\
\hline Etienne BARAS & Belgium & Svein LOKKEBORG & Norway \\
\hline Toni BEDDOW & Canada & Pierre LOONIS & France \\
\hline Vincent BENECH & Mali & Don MacCUBBING & U.K. \\
\hline Stephen BLACK & Ireland & Ridha MALLEKH & France \\
\hline Drew BODALY & Canada & Gerd MARMULLA & Italy \\
\hline Gunnbjorn BREMSET & Norway & Francis MARSAC & Seychelles \\
\hline Andre BREUKELAAR & The Netherlands & Theresa MARTINELLI & U.S.A. \\
\hline Catherine BRUGEL & France & Andy MOORE & U.K. \\
\hline Eilif BRODTKORB & Norway & George NIEZGODA & Canada \\
\hline Patrice CAYRE & France & Mark John O'CONNELL & U.K. \\
\hline Guy CLAIREAUX & France & Ron O'DOR & Canada \\
\hline Stuart CLOUGH & U.K. & Odd Arild OLSEN & Norway \\
\hline Johan COECK & Belgium & Dominique OMBREDANE & France \\
\hline Sandra COLAZZO & Belgium & Michael OVIDIO & Belgium \\
\hline Martin COLLINS & U.K. & Armin PETER & Switzerland \\
\hline Gabriel EDEL & France & Pascal ROCHE & France \\
\hline Bruno ERNANDE & France & Ian RUSSELL & U.K. \\
\hline Koos FOCKENS & The Netherlands & Richard SABATIE & France \\
\hline Frank FREDRICH & Germany & Stefan SCHMUTZ & Austria \\
\hline Mathieu GERLIER & France & Henrik SCHURMANN & Denmark \\
\hline Eduardo GONZALEZ- & & David SCRUTON & Canada \\
\hline GURRIARAN & Spain & Mitchell SISAK & Canada \\
\hline Juliette GUET & Norway & Per Olav SKJERVOLD & Norway \\
\hline Eli Kyrkjebo HAUGLAND & Norway & Gordon SMITH & U.K. \\
\hline Tor HEGGBERGET & Norway & Philip SMITH & U.K. \\
\hline Cyril HERISSE & France & Kim SUN & The Netherlands \\
\hline Marianne HOLM & Norway & Fredrik SUNDSTROM & Sweden \\
\hline Martin HUBER & Switzerland & Dany SUREAU & France \\
\hline George JACKSON & Australia & John TAYLOR & U.K. \\
\hline Niels JEPSEN & Denmark & Eva THORSTAD & Norway \\
\hline David JOHNSTON & Canada & François TRAVADE & France \\
\hline Erwan JOSSE & French Polynesia & Gordon URQUHART & U.K. \\
\hline Adrian JOWITT & U.K. & Fred VOEGELI & Canada \\
\hline Anders KOED & Denmark & Magnus WAHLBERG & Sweden \\
\hline Françoise LAGARDÈRE & France & Dale WEBBER & Canada \\
\hline Jean-Paul LAGARDÈRE & France & Hakan WESTERBERG & Sweden \\
\hline
\end{tabular}

